\title{
Online Millennial Women's Financial Literation in Tulungagung District, Indonesia
}

\author{
Sri Umi Mintarti ${ }^{1,}$ Dian Rachmawati ${ }^{2 *}$, Sri Handayani ${ }^{3}$, Ahmad Munjin Nasih $^{4}$, \\ Halimah Mohd. Yusof ${ }^{5}$
}

\author{
1, 2, 3, 4 Universitas Negeri Malang \\ ${ }^{5}$ Universiti Teknologi Malaysia \\ *Corresponding author. Email: dian.rachmawati.fe@um.ac.id
}

\begin{abstract}
This research theme is financial literation. This study aims to measure the level of financial literacy of millennials which have online businesses in Tulungagung District 2020. The are 31 respondents who share their views and give their answer to this research. The are several aspects of financial literacy of which being chosen in this study, namely personal finance, savings and deposits, insurance, and investment. This is also a descriptive study based on a survey and deep interview of research subjects. The data gained from the dept interview and questionnaires. And the result shows that the level of financial literacy towards millennials which run online businesses in Kabupaten Tulungagung was low and it shows by the number of percentage $39,7 \%$.
\end{abstract}

Keywords: Financial literacy, Millennials, Economy, Finance.

\section{INTRODUCTION}

An understanding of financial literacy is essential for every individual to be able to manage and plan their finances. This also applies to entrepreneurs of Micro, Small and Medium Enterprises (MSMEs). In managing a business or business, it is also necessary to understand that knowledge of financial literacy is very important. It doesn't matter that the millennial generation or before, knowledge of financial literacy will provide maximum benefits to the business that is being worked on. Business failure is mostly caused by managerial failures, both in terms of operations and, more importantly, finance. So the need for knowledge of financial literacy as expressed by the Financial Services Authority (2013) states that the level of financial literacy has a positive relationship with income and education levels. [1]

High knowledge of financial literacy will make business actors in this case millennial women able to generate high income too. The level of financial literacy knowledge will encourage business actors to act effectively and efficiently in managing their business. But the fact is in life that not everyone has the knowledge and understanding of finance that is in accordance with the business being run. The fact is that in everyday life, not everyone has sufficient financial knowledge or is well literate [2]. This minimal financial knowledge makes financial management in business less good. This is because managing healthy money requires several fundamental factors that need to be improved and one of them is financial literacy [3].

The importance of financial literacy in managing a business cannot be denied that individual knowledge on financial literacy will have a good effect on their business. Financial literacy is an individual's ability to apply financial management, both in obtaining and evaluating information that is generally intended for decision making and seeing the consequences received [4]. Low knowledge of financial literacy will lead to misstated decision making. So that it will be risky to the business that is being carried out. Making wrong decisions will end in poor and ineffective financial management which can result in the behavior of people who are vulnerable to financial crises and have the potential to suffer losses due to crimes in the financial sector [5].

Regarding millennial women in doing business, the level of knowledge of millennial women about financial literacy in managing their businesses is still low. This is in line with what [6] stated that women, minorities and 
low-income groups tend to have low levels of financial literacy. As described above, this research will focus on women entrepreneurs in the sense that millennial women understand financial literacy.

\subsection{Financial Literacy}

The ability of everyone in managing financial affairs in everyday life is included in the term financial literacy [7]. Financial literacy is not limited to understanding knowledge, skills and belief in existing financial institutions, products and services, but attitudes and behavior also have an influence in increasing financial literacy for the realization of public welfare [8].

According to [9] in [10] states that financial literacy can be seen as an investment in human capital and can help in the context of decisions about pensions, savings, credit, and decisions. other finances.

\subsection{Financial Literacy Framework}

Based on qualitative research conducted by [11], the variables that affect financial literacy are then developed into five variables. According to Firli, the variables that affect financial literacy can be grouped into five variables, namely: (1) Personal Sociodemographic characteristics; (2) Financial knowledge; (3) Financial Behavior; (4) Financial Attitude; (5) Financial Training

\subsection{Personal Socio-Demographic Characteristics}

[12] [13] states that gender, age, marital status, family income, financial decision-making processes, budgeting and expenditure, position, qualifications are factors that affect financial literacy [11] also argue that there are many factors that affect the level of financial literacy, such as employment, educational background, household income, demographic factors which are statistically significant to the level of financial literacy.

\subsection{Financial Knowledge}

Research shows that low financial literacy is the result of a lack of financial knowledge [14] [15]. [9] state that someone with a low level of financial literacy is usually correlated with low income, low education, and low wealth. Therefore, increasing financial knowledge for households is needed so that they can participate in a sustainable manner in the financial market [16].

\subsection{Financial Behavior}

[11] states that financial literacy is also related to behavior. A person's financial behavior can be measured by their behavior in managing basic finances, for example in terms of saving, consumption, and even investing. A person's financial behavior can also be indicated by one's participation in buying financial products, such as buying stocks, bonds, gold, foreign exchange, time deposits.

\subsection{Financial Attitude}

Financial attitude is measured by one's attitude towards money and financial responsibility [11]. [17] found that respondents' attitudes to risk correlate with share ownership. Those who are not willing to take risks are less likely to participate in the stock market. Therefore, financial attitude is one measure to measure a person's level of financial literacy. [18] [19] suggest that financial attitudes correlate with the level of financial problems [20].

\subsection{Financial Training}

People who receive financial training will have deeper knowledge in finance and will make better decisions, so it can be said that the person is more financially literate [11]. Financial training conducted for farmers in Rwanda (India) Village found that the training carried out increased savings, encouraged farmers to take loans, increased new income-generating activities, and encouraged farmers to pay their debts [21]. Financial education related to personal finance allows individuals to take effective actions to improve financial well-being and avoid financial problems [16].

\section{METHODS}

This study uses a descriptive research design that will describe the financial literacy of millennial women in managing online businesses in Tulungagung Regency. The subject of this research is the millennial generation with an age range of 17 years 
to 35 years. Which subject is a woman who has an online business in Tulungagung Regency.

Data collection was carried out by observation. This activity was carried out to obtain data on the financial literacy of millennial women in managing integrated online businesses in Tulungagung Regency. Observations were made before finding out how millennial women's financial literacy is in managing online businesses in Tulungagung Regency. In-depth interviews were conducted to obtain

Table 1. The grid of research instruments on the level of financial literacy of millennial women in managing online businesses in Tulungagung in the aspects of basic knowledge of personal finance, savings, loans, insurance and investmen

\begin{tabular}{|c|c|}
\hline Aspect & Question \\
\hline $\begin{array}{l}\text { General } \\
\text { knowledge of } \\
\text { personal } \\
\text { finance }\end{array}$ & $\begin{array}{l}\text { 1. Knowledge of wants and needs } \\
\text { 2. Ability to make priorities } \\
\text { 3. Provision of emergency funds } \\
\text { 4. Planning funds pensiu n } \\
\text { 5. Financial literacy access } \\
\text { information } \\
\text { 6. The benefit of socialization and } \\
\text { training on financial institution } \\
\text { products and services }\end{array}$ \\
\hline $\begin{array}{l}\text { Savings and } \\
\text { loans }\end{array}$ & $\begin{array}{l}\text { 7. Financial records } \\
\text { 8. Credit withdrawal access } \\
\text { 9. Ownership of savings from } \\
\text { business profits } \\
\text { 10. The amount of debt covered every } \\
\text { month } \\
\text { 11. Ability to calculate simple bank } \\
\text { interest }\end{array}$ \\
\hline A insurance & $\begin{array}{l}\text { 12. Awareness of covering risks } \\
\text { through insurance }\end{array}$ \\
\hline Investment & 13. Ownership of capital reserves \\
\hline
\end{tabular}

Source: Chen and Volpe (1998) and Firli (2017)

The data analysis technique used in this research is descriptive analysis, namely the analysis technique that describes the characteristics of the data.

The results of these calculations will then be compared with the criteria for financial literacy levels according to Chen and Volpe, namely financial literacy is said to be high if the correct score exceeds $80 \%$, medium if the correct score is between $60-80 \%$, and low if the correct score is less than $60 \%$. Furthermore, the conclusion is drawn using the formula:

$\%$ average $=($ total number of $\%$ correct answers $/$ items) clear data on the financial literacy of millennial women in managing online businesses in Tulungagung Regency.

This study uses three research instruments, observation sheets conducted before and after, questionnaires and in-depth interviews to obtain accurate and stable information. The questionnaires distributed contain questions about financial knowledge in general. Savings, loans and investments.

Table 2. Categories of Financial Literacy Levels

\begin{tabular}{|l|l|}
\hline The total score is correct & $\begin{array}{l}\text { Financial literacy level } \\
\text { category }\end{array}$ \\
\hline $\mathbf{8} \mathbf{8 0 \%}$ & High \\
\hline $\mathbf{6 0 \%} \mathbf{- 8 0 \%}$ & Intermediate \\
\hline $\mathbf{6 0 0 \%}$ & R endah \\
\hline
\end{tabular}

Source: Chen \& Volpe (1998)

\section{RESULTS AND DISCUSSION}

This research is useful to determine the level of financial literacy of millennials who have online businesses in Tulungagung Regency. The level of financial literacy will be reflected in the results of filling out the questionnaires that have been distributed in Tulungagung Regency. Based on the questionnaire that had been distributed, 31 people were willing to become respondents.

Demographically, based on the data that has been filled in the research questionnaire, it shows that the majority of millennial women who trade online are 19 and 20 years old, namely $19.35 \%$ respectively. Then the ages of 21 and 22 years respectively were $12.9 \%, 18$ years old was $9.67 \%$, ages 17 and 26 were $6.45 \%$ respectively, and the rest were 29,36 , and 43 years old. With the majority level of education is SMA, reaching $45 \%$, then followed by graduates of S1 / D4 as much as $39 \%$. While the rest have junior high school education, vocational school, workers and employees. These 31 respondents are millennials who have online businesses in the culinary field (33\%), fashion and beauty (32\%), household needs (29\%), design services (3\%), and Murotal Al-Qur'an (3\%).

The results of data processing regarding the level of financial literacy of millennials who have online businesses in Tulungagung Regency are grouped into the following aspects of knowledge:

a. Aspects Knowledge common personal finance

b. Savings and loans aspects

c. Insurance aspect

d. Investment aspect 
Further descriptions regarding the elaboration of these aspects can be seen in the following table:

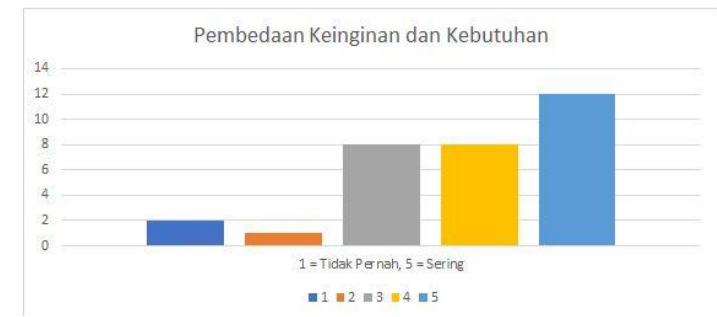

Figure 1. Knowledge of wants and needs

In managing personal finances, the majority of online traders are able to distinguish between wants and needs, which is $38.7 \%$. However, $6.5 \%$ of traders never differentiate between wants and needs.

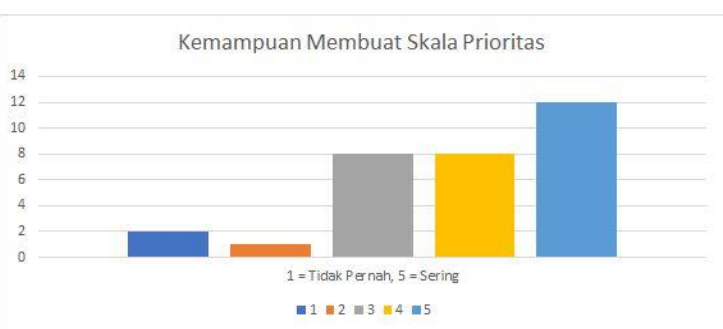

Figure 2. Ability to Make Priority Scale

In meeting personal and business needs, the majority of online merchants have been able to make a priority scale $(38.7 \%)$. However, $3.2 \%$ of online merchants never prioritize at all

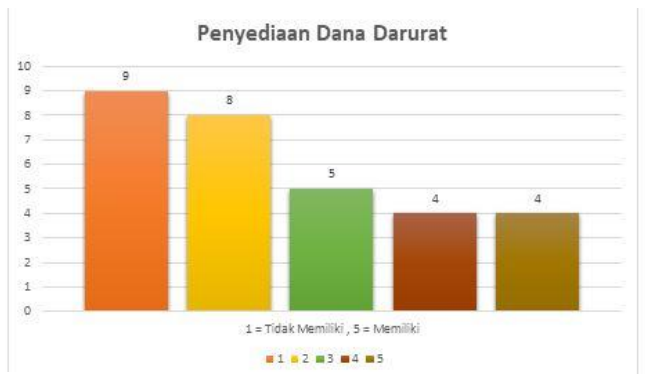

Figure 3. Provision of Emergency Funds (3-6 Times Total Expenditures Each Month)

As many as $30 \%$ of online merchants in Tulungagung do not have an emergency fund supply of 3-6 times the amount of expenditure each month. The remaining $12 \%$ of them have an emergency fund even though the amount does not reach 3-6 monthly expenses.

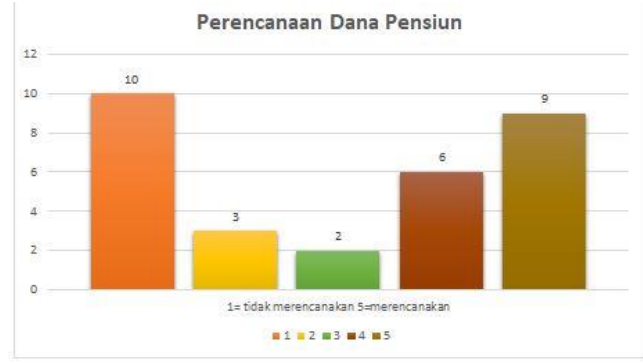

Figure 4 Provision of Pension Funds

The majority of online merchants do not prepare pension funds for the long term. However, there are those who are already planning a pension fund. And $29 \%$ have plans for a pension fund.

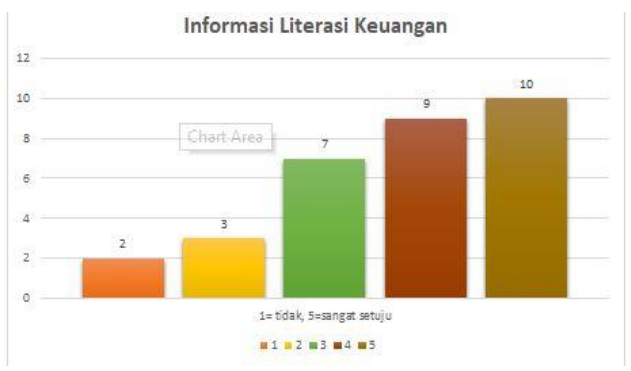

Figure 5 Information on Access to Financial Literacy

Financial literacy information can be accessed easily by online traders, where $32.2 \%$ of online merchants have access to financial literacy information. However, $6.5 \%$ of the online traders have difficulty accessing financial literacy information.

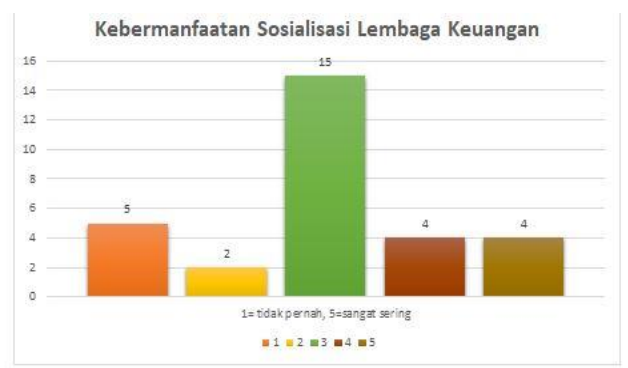

Figure 6 Benefits of Socialization and Training on Financial Institution Products and Services

The existence of socialization and training about financial institution products and services is quite useful for online traders in Tulungagung. However, $13.3 \%$ felt that they did not benefit from the socialization. And as many as $12 \%$ of respondents realized the benefits of this activity. 


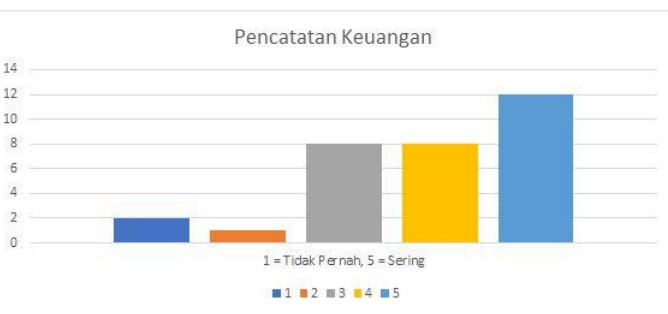

Figure 7. Financial Records

As a businessman, online merchants often carry out financial records regularly, amounting to $38.7 \%$. However, $12.9 \%$ of these online merchants have never routinely recorded their business finances.

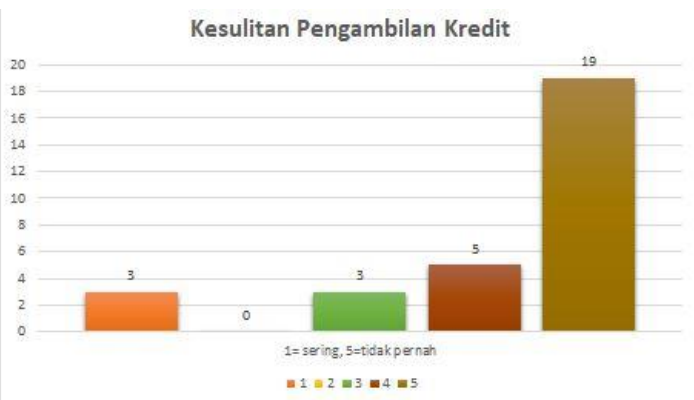

Figure 8 Access to Withdrawal of Credit

$63.3 \%$ of online merchants in Tulungagung have no difficulty taking credit, both at bank financial institutions and non-bank financial institutions.

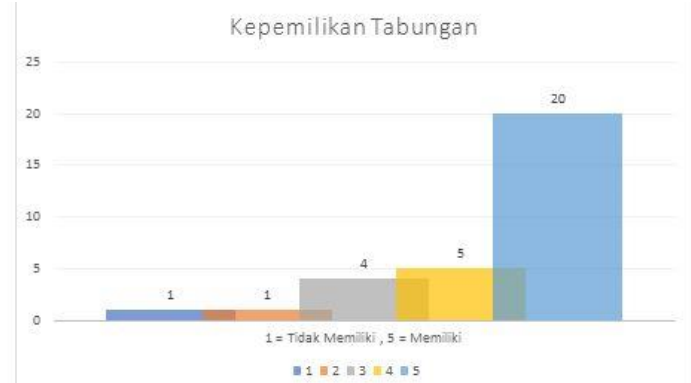

Figure 9 Ownership of Savings from Business Profits

Based on a survey that has been conducted, $64.5 \%$ of online merchants have savings that come from set aside business profits. However, there are $3.2 \%$ of traders who have absolutely no savings from their business profits.

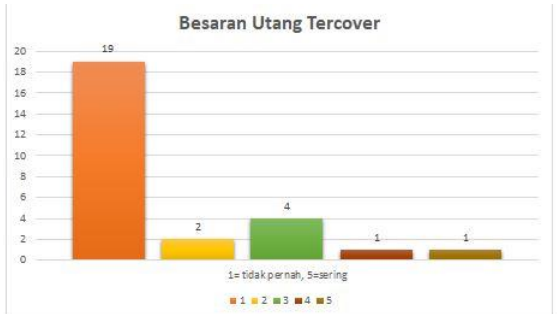

Figure 10 Amount of Debt Covered Each Month
Based on survey results, $70.4 \%$ of online merchants never cover their debts every month. And as much as $29.6 \%$ cover their debts every month.

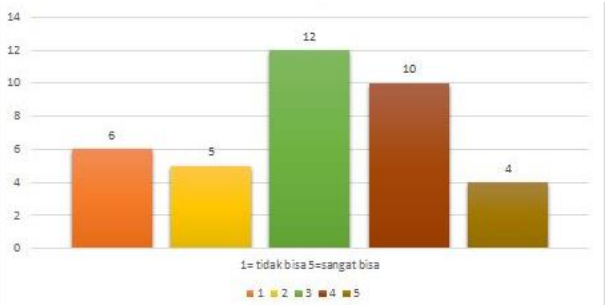

Figure 11 Ability to Calculate Simple Bank Interest

In calculating the amount of bank interest in a simple way, online traders in general have mastered even though they are not very proficient. Only $13.3 \%$ of traders were proficient in calculating simple interest on debt. However, $20 \%$ of online merchants cannot calculate the amount of interest on the debt.

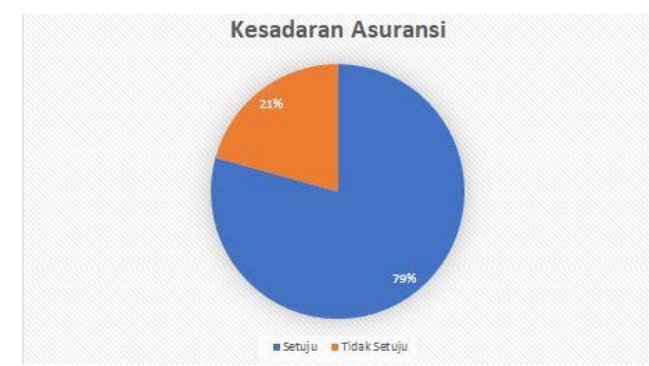

Figure 12 Awareness of Risk Coverage through Insurance

The awareness of the need to cover risks through participation in insurance has been raised by $79 \%$ of online merchants.

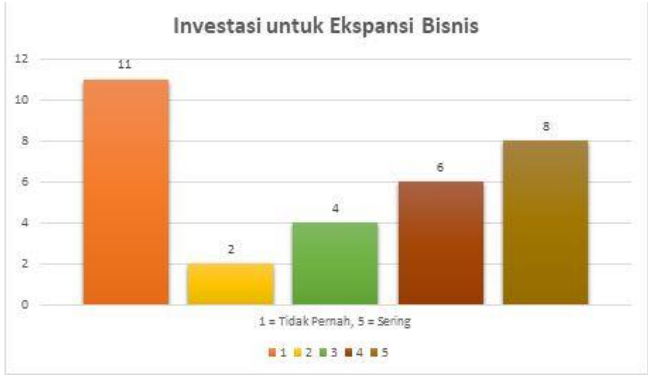

Figure13 Investment / Investment for Business Expansion

Based on the survey results, online traders in Tulungagung have never invested in business expansion, which is $35.5 \%$. As many as $64.5 \%$ have invested for business expansion.

Based on the results of the percentage of positive answers from the 13 aspects above, the total average number of positive answers is $=515.5 \% / 13=$ $39.7 \%$. The level of financial literacy for millennials who manage online businesses in Tulungagung Regency is $39.7 \%$. When viewed from the category of financial literacy level, this condition is included in the low financial literacy level. 


\section{CONCLUSIONS}

Based on the results of research and discussion, where the analysis of the level of financial literacy of millennials who have online businesses in Tulungagung is $39.7 \%$.

Referring to the category of financial liability levels by [14], this condition is included in the low level of financial literacy. So that further activities are needed to improve the quality of financial literacy in Tulungagung district, especially for millennial umkm women online.

Financial literacy from the aspect of general knowledge of personal finance in online female SMEs can be said based on the results of questionnaires and in-depth interviews regarding the differentiation between wants and needs, determining the priority scale. Meanwhile, the aspect of financial literacy in savings and loans, insurance and investment is still very low. so it still needs to increase the scale of production and improve marketing technology.

\section{AUTHORS' CONTRIBUTIONS}

The first author as the person in charge and determinant of the research topic and provides the basic concept of research development. The second author compiles article 1, literature review and research methods, the third author is the compiler of article 2 and data processor. The fourth author is the evaluator and reviewer of articles 1 and 2 . and the fifth writer is the mentor and reviewer of the articles to be submitted in journals or proceedings

\section{ACKNOWLEDGMENTS}

We would like to express our gratitude to research and community service institutions (LP2M) Universitas Negeri Malang who has facilitated and provided funding for this research. the informants and field workers who assisted us in completing this research and article.

\section{REFERENCES}

[1] Otoritas Jasa Keuangan (2013) Indonesian National Strategy For Financial Literacy. Jakarta. www.ojk.go.id.

[2] Yuliana, V. “Analisis Pengaruh Variabel Keuangan Dan Non Keuangan Terhadap Initial Return Dan Return Setelah IPO”. Management Analysis Journal. 2(2), 2013.

[3] Rasyid, R. “Analisis Tingkat Literasi keuangan Mahasiswa Program Studi Manajemen Fakultas Ekonomi Universias Negeri padang”. Jurnal Kajian Manajemen Bisnis vol. (01) 1, pp 91-108, 2012.
[4] Ningtyas, M., N. "Literasi Keuangan Pada Generasi Milenial". Jurnal Ilmiah Bisnis dan Ekonomi Asia (13) 1 pp 20-27, 2019.

[5] Braunstein, S. dan Welch, C. "Financial literacy: An overview of practice, research, and policy," Federal Reserve Bulletin, vol. 88(11), pp. 445-457, 2002.

[6] Amari, M., \& Jarboui, A. "Financial literacy and economics education among young adults: An observation from Tunisia". Journal of Business \& Finance Librarianship, 20(3), 209-219, 2015.

[7] C. Aprea et al., International Handbook of Financial Literacy. Springer Sciences. Business Media Singapore, 2016.

[8] Otoritas Jasa Keuangan. Survei Literasi Nasional Literasi Keuangan Indonesia (Revisi 2017), 2017.

[9] Lusardi, A. dan Mitchell, O. S. "The Economic Importance of Financial Literacy: Theory and Evidence," 52(1), hal. 1-40, 2017. doi: (http://dx.doi.org/10.1257/jel.52.1.1.)

[10] Amagir, A., Groot, W., Maassen van den Brink, H., \& Wilschut, A. A review of financial-literacy education programs for children and adolescents. Citizenship, Social and Economics Education, 2017. https://doi.org/10.1177/2047173417719555Garman, E. Thomas dan Forgue, Raymond E., 2010. Personal Finance International Edition, South Western Cengage Learning, Canada.

[11] Firli, A. "Factors that Influence Financial Literacy: A conceptual Framework," hal. 1-7, 2017. doi: 10.1088/1742-6596/755/1/011001.

[12] Agarwalla, S. K. et al. Savings, Borrowings and Remittance Behaviour of Migrant Workers in Urban India, 2016.

[13] Bashir, S., Zeeshan, M., Sabbar, S., Hussain, R.I., $\&$ Sarki, I.H. Impact of cultural values and life style on impulse buying behavior: A case study of Pakistan. International Review of Management and Business Research. 2 (1), 193-200, 2013.

[14] Chen, H. dan Volpe, R. P. “An analysis of personal financial literacy among college students," Financial Services Review, vo7(2), pp. 107-128, 1998.

doi: 10.1016/S1057-0810(99)80006-7. L.

[15] Carpena, F. et al. Unpacking the Causal Chain of Financial Literacy, The World Bank Development Research Group, 2011.

doi: 10.1596/1813-9450-5798.

[16] Ramachandran, D. R. "Financial Literacy". The Demand Side of Financial Inclusion. SSRN Electronic Journal, October, 2011. (https://doi.org/10.2139/ssrn.1958417)

[17] Van Rooji, Maarten, Annamaria Lusardi, and Rob Alessie. "Financial Literacy and Stock Market 
Participation.” Journal of Financial Economics vol. 101 (2), pp. 449-72, 2011.

[18] Hayhoe, C., Leach, L., \& Turner, P. "Discriminating the number of credit cards held by college students using credit and money attitudes". Journal of Economic Psychology, vol. 20(2), pp. 643-656, 1999.

[19] Lim, V., \& Teo, T. "Sex, money and financial hardship: An empirical study of attitudes towards money among undergraduates in Singapore". Journal of Economic Psychology, vol. 18, pp. 369386, 1997.

[20] Herdjiono \& Damanik, "Pengaruh Financial Attitude, Financial Knowledge, Parental Income Terhadap Financial Management Behavior”. Jurnal Manajemen Teori dan Terapan, Universitas Airlangga: Surabaya, vol. 9 (3), 2016.

[21] Sayinzoga, Aussi and Bulte, Erwin H. and Lensink, Robert, "Financial Literacy and Financial Behaviour: Experimental Evidence from Rural Rwanda". The Economic Journal, vol. 126 (594), pp. 1571-1599, August 2016.

SSRN: https://ssrn.com/abstract=2815204 or http://d X.doi.org/10.1111/ecoj.12217 